\title{
MEETING FIRST-TIME BUYERS' HOUSING NEEDS AND PREFERENCES IN GREATER KUALA LUMPUR
}

\begin{abstract}
:
The high prices of houses in Greater Kuala Lumpur have made it difficult for first-time homebuyers to own a house. As a result, affordable housing schemes were introduced recently to help them become home owners. The Malaysian government has launched many kinds of public low-cost housing schemes; however, many housing projects which resulted from these schemes have turned into slums that do not provide wholesome environment for families to live. In order to avoid building more slums and benefit more young buyers from the scheme, the goal of this paper is to determine the right housing attributes required for first-time homebuyers in the urban area. A total of 300 questionnaires were distributed to young Malaysians in Greater KL with 265 questionnaires were returned. Results revealed that accessibility and neighborhood environment play a role in the decision to own. It can also be seen that ecologically friendly homes that embrace sustainability were important considerations when buying a home.
\end{abstract}

Keywords: Housing Attributes, Homeownership, Affordable Housing Scheme, Greater Kuala Lumpur, Malaysia 


\section{INTRODUCTION}

A roof over one's head is one of a few necessities in life. Having a house has always been part of the Malaysian dream (Tan, 2008). In recent times, however, it has been a stretch for the average Malaysian to own a home. Prices of property in the hot areas of the Grater Kuala Lumpur (KL) rose about 35\% in 2010 (Ministry of Finance's Valuation and Property Service Department, 2011) and home price inflation appears to be spreading elsewhere in the country now. This is especially tough for the younger Generation Y, whose wage increases have in no way kept pace with house price inflation over the past 10 years.

\section{Greater Kuala Lumpur (KL)}

Greater Kuala Lumpur, hereafter referred to as Greater KL, constitutes one of the 12 National Key Economic Areas (NKEAs) featured in the Economic Transformation Program. The ETP serves as a roadmap for Malaysia to attain the status of a developed economy with a Gross National Income (GNI) of USD 15, 000 per capita by 2020. Although Greater KL is one of the iconic cities of Southeast Asia, its livability lags many other Asian Cities. In the Mercer Quality of Living Survey 2010, Kuala Lumpur is ranked 138 out of 221 cities surveyed while in the Economist Intelligence Unit (EIU) Livability Index Survey 2010, Kuala Lumpur ranks $10^{\text {th }}$ out of 31 Asian cities in the EIU index. As a city, Greater KL aims to achieve a top-20 ranking in the Economic Intelligence Unit Livability Index Survey. Such developments create a need to provide adequate housing with quality and harmonious living environment for all needy Malaysians irrespective of race and religion.

\section{Affordable Housing Schemes for First-Time Homebuyers in Greater KL}

In Malaysia, the public sector holds an important social responsibility in fulfilling the needs of housing for those in the lower income group and the public sector. The provision of houses for other Malaysians has been left to the private sector, but with prices of home and land skyrocketing, the private sector has in recent years only concentrated on high-end homes. Even though there is a requirement for private housing developers to include affordable housing 
components in their projects, this is hardly adhered to these days. The absence of large-scale townships makes it uneconomical to comply with this ruling because most of today's development projects are on much smaller plots of land.

It appears that public and private sectors should tackle the housing provision of the Malaysians effectively and efficiently, particularly first-time homebuyers before negative feelings fester and overflow into a backlash. The recent announcement of My First Home Scheme by Malaysian Prime Minister in March 2011 stated that the scheme was targeted at young working Malaysians earning RM 3,000 or less to acquire homes costing from RM 100, 000 to RM 220, 000 (exchange rate US1 = RM3). This scheme is part of the whole affordable housing schemes that allows $100 \%$ financing for first-time homebuyers (Cheng, 2011). There have been debates over the house price cap of RM 220,000 and the income cap of RM 3,000 per month under this scheme, especially for young Malaysians working in Greater KL. The cap on prices excludes desirable locations that housing developers can build on because of high land prices in the urban area. At this price range, most of housing projects will be either outside or on the fringes of Greater KL. As reported by the Ministry of Finance's Valuation and Property Service Department (2010), the estimated average prices for all houses in Kuala Lumpur and Selangor were RM 432, 181 and RM 290, 481 respectively as of the third quarter of 2010.

In view of benefiting more first-time buyers, the government subsequently launched the 1 Malaysia People's Housing Scheme (PR1MA) later. This scheme, which is an addition to the My First Home Scheme, will see stratified units priced between RM 220, 000 and RM 300, 000 being built for first-time buyers with a household income of less RM 6,000 a month (Annuar, 2011). Under this program, eligible buyers can apply for an apartment unit between 800 to 1,400 square feet with three bedrooms and 2 bathrooms. The eligible buyers are eligible for a loan of up to $105 \%$ from financial institutions with a 30 -year payment scheme. The extra $5 \%$ from the loan is meant to assist the buyers to cover the cost of insurance and legal aspects of the purchase.

It seems that it is a great challenge to provide more decent housing under the scheme in Greater KL to many young Malaysians who migrate from less developed parts of the country in search of jobs. Furthermore, the Malaysian government has launched many kinds of public low-cost 
housing schemes for the past 20 years, but most of them have failed to provide an improved quality of life to their inhabitants. In fact, many of the housing areas developed based on these schemes have turned into slums that do not provide wholesome environment for families. In Malaysia, low-cost housing is priced between RM 35, 000 and RM 42, 000 each. Because of that price, many of these units are small at 650 square feet. The lack of space and privacy has resulted in children spending their time at corridors, on the landings of fire escape or at the car park bays provided (Tan, 2011c).

In order to prevent a similar occurrence as how most of the low-cost houses in Greater KL have turned out today, it is important to ensure the housing development projects under the affording housing scheme for first-time buyers are properly designed and planned. Therefore, it is critical for public and private house builders to identify and meet first-time buyers' housing needs and preferences that will encourage them to own a house.

The housing industry will continue evolving to suit the ever-changing households' preferences which create motivation for households to own a house (Aarland \& Nordvik, 2007). Conventionally, housing is mainly for the need of physical sheltering; however, as time passes, housing needs encompass broader setting (Foley, 1980). As pointed by Yam and Ismail (2008), housing developments in Malaysia have experienced significant transformation from 1985-2004, where the buyer preferences changed from basic shelter to quality living environment. Furthermore, Tan (2011a) stated that when households purchase or rent a housing unit, they have other concerns towards the housing unit such as location, environmental amenities, symbolic characteristics and investment.

There are literatures to study home owning preferences of first-time homebuyers in developed countries (Reed \& Mills, 2007; Friedman, 2000). However, there is little evidence to examine first-time homebuyers' homeownership preferences in the Malaysian context. Therefore, this research intends to fill the gap that currently exists in literature by determining home owning preferences among first-time house buyers in Malaysia. With this background, this paper aims to examine empirically the right housing attributes required for first-time homebuyers in Greater KL to own their home. 


\section{LITERATURE REVIEW}

\section{Home Owning}

According to Saunders (1990), people have natural preference towards home owning. Saunders (1990) further explained that people's natural preference in terms of their controlling intuition and the aspiration to mark down their own territory are the reasons of home owning. The decision to own a house might be affected by a desire to have a property of one's own, a desire for stability and pride of ownership, things that cannot be easily captured by age or income (Haurin et al., 2002). There is much evidence that motivation has been an important reason in the explanation of homeownership (Tan, 2009). Following psychologist Abraham Maslow's motivation theory, owning a house may satisfy more than wide-ranging households' needs. For example, a home offers basic protection from physical discomfort of harm (shelter). A home can also provide protection from unwanted social contact (privacy). As such, shelter and privacy form the 'physiological' and 'safety' dimensions of needs.

The benefits of home owning to both owners and society can be found in many housing studies ranging from socio benefits to economic benefits. Haurin et al., (2002) proved that owning a house improves the home environment in which a child lives, improves a child's cognitive ability and reduces behavior problems. Rohe et al., (2001) and Tan (2009) both pointed out home owning increases households' self-esteem and life satisfaction because it can be viewed as a significant achievement of a household. Increased parental self-esteem has resulted in a greater emotional support for the households' children. Green \& White (1997) also found that children of homeowners stay in school longer than children of renters. From an investment perspective, owning a house serves to create wealth in terms of capital appreciation and decreasing mortgage liabilities (Rohe et al., 2001). According to Bourassa (1996), the largest portion of households' liquid wealth is in the form of home equity, which is calculated as the home owner's estimate of house values less any outstanding mortgage debt.

\section{Housing Attributes}


Wang \& Li (2006) argued that buying a house is a multi-elements exercise, involving tenure options, housing types, neighborhood, location etc. as housing preferences will thereafter be determined by a set of various attributes of the housing households will search for (Hurtubia et al., 2010). Housing attributes have been shown in many literatures ranging from intrinsic housing attributes such as interior living spaces (Lindberg et al., 1989; Cupchik et al., 2003), extrinsic attributes such as exterior design and exterior space (Bhatti \& Church, 2004) to neighborhood and locational indicators such as environmental qualities (Zabel \& Kiel, 2000; Yusuf \& Resosudarmo, 2009; Tan, 2011a).

With respect to the locational attributes of housing, distance to the workplace, schools, retailing outlets and public transportation stations have been found to be significant considerations for house buying. The study by Kauko (2007) indicated that a good location is an important factor that determines the success or failure of the housing development project. Crane (1996) defined distance to work as secure job relations, low house moving expenses, fewer job turnovers, low transportation costs and additional time available for household to deal with day by day events. Levine (1998) pointed that travel time may have an effect on households' home owning preferences, particularly for low-to-moderate income households. Generally households would like to choose a house that is convenient to their working place (Tu \& Goldfinch, 1996). According to Tan (2011a), distance to public-community amenities could mean providing convenience to get to local amenities such as school, retailers and public transport. Distance to school is principally relevant for households with children when deciding the location for a house (Clark et al., 2006). Similarly, distance to retailers could be one of main considerations for house buyers as retailing is one of the most vital aspects in the life of the households (Tan, 2011a). In China, living convenience to daily goods shopping is an important consideration for homeownership preference (Wang \& Li, 2006) Despite the benefits of proximity to retailers, it is documented that high concentration of retailers could discourage the preference of households on that particular location due to overcrowding and noise pollution (Hurtubia et al., 2010). Additionally, housing units which are located within a close distance to green or recreational park are highly favorable and preferred by households (Luttik, 2000; Lo \& Jim, 2010). It has been shown that accessible green spaces near homes could raise house price by 5-6 percent (Tajima, 2003). 
There were a number of research conducted on neighborhood attributes of housing ranging from sights of trees and water (Luttik, 2000), air quality (Zabel \& Kiel, 2000) to neighborhood crime (Karim, 2008). As stated by Tan (2011a), a house that is located in a good neighborhood is preferred as households are willing to pay extra for a house with good environmental qualities in the neighborhood. The study by Yusuf \& Resosudarmo (2009) on the matter of cleaner air has clearly demonstrated the importance of air quality on households' homeownership preferences in Indonesia. Their findings revealed that all of the coefficients of pollution variables with the exception of small particulates in terms of sulphur dioxide, carbon monoxide, nitrogen oxide, hydro carbon and lead were negative, indicating that better air quality is related to higher property prices. Additionally, house prices can be susceptible towards environmental conditions such as water and noise pollution. As pointed by Segerson (2001) and Iman et al (2009), water and noise pollution will negatively affect land and property prices. It is also documented that households are willing to pay more to live in a neighborhood with low crime rate and other security problems (Wang \& Li, 2006). Tan (2011a) noted that a good housing developer should take safety aspect of the neighborhood into consideration in housing development project. This is to assure that households living in the neighborhood are safe, secure and their well-beings are guaranteed. Tan (2011a) further revealed that the gated-guarded neighborhood with landscaped compound could raise housing property prices by $18.1 \%$, indicating households will place preference on the gated-guarded neighborhood when it comes to the matter of living in a safe and secure condition.

It is widely known that housing markets have largely explored the requirement for structural attributes of housing (Fierro et al, 2009). These structural attributes of housing have been brought up in many literatures as influencing households' house buying preferences (Opoku \& Abdul-Muhmin, 2010). The most common structural attributes that could have impacts on home owning preferences are size of housing lot, number of bedrooms and bathrooms, and presence of garden in a house. According to Clark \& Onaka (1983), space is a leading aspect within the household decision-making process for house buying preferences. Clark et al. (2006) pointed that most of the households at all times make an effort to increase their existing size of housing lot as it symbolizes more luxury for the inhabitants. Hurtubia et al. (2010) revealed that the number of 
rooms or bathrooms in a house is an important feature to be considered by households in making home owning decisions particularly in western countries. In Saudi Arabia, private living space such as the number of bedrooms, the size of bedrooms and the number of bathrooms are considered the key attributes of housing because private living space may be directly related to the issue of privacy (Opoku \& Abdul-Muhmin, 2010). Households also place importance on the presence of garden in their house for children's activities. Furthermore, families with young children often have the propensity to choose gardens rather than balconies in making housing choice (Hurtubia et al., 2010). Also, studies from the European (Luttik, 2000) and North American (Tajima, 2003) countries have proven that households are willing to pay more for garden and green space. As pointed by Al-Hagla (2008) and Choguill (2008), gardens play an important role in supporting social sustainability as their primary function is for relaxation and social purposes. The issues of sustainability have become ever more paramount in today's housing market (Tan, 2011b). House builders are urged to design houses for sustainable living, which is in tandem with the government's efforts to go green. Housing developers have recognized the growing market demand for environmentally sustainable housing development projects (Tan, 2011b). The green house will boast eco-friendly and energy-reduction features. These houses aim for zero carbon emissions by maximizing passing design principles, minimizing energy consumption, adopting onsite energy generation, utilizing renewable energy technologies, minimizing the use of highly resource intensive materials for the construction of new houses and maximizing the use of water neutral through the reduction of mains water consumption, rainwater harvesting and greywater recycling. It is reasonable to believe that there is enough demand for such homes among house buyers in Malaysia.

Numerous empirical studies have identified the relative importance of socio-cultural attributes of housing in house buying decisions (Jabareen, 2005). Sultan Sidi (2010) explained that these attributes can be seen mostly in the settlement pattern and life style, for instance, the Feng Shui system of the Asian society. Feng Shui is literally interpreted as wind and water. It is a conventional practice to harmonize people with their surroundings and to make prosperity. The Feng Shus is associated with Qi, which is believed to be the fundamental energy would promote health, peace and fortune (Xu, 1998). Most households will prefer houses that promote good Qi in Asian countries (Tse \& Love, 2000; Wang \& Li, 2006). For example, a good direction that the 
house faces, which affects the sunlight penetration and air ventilation is one of key considerations among households in Guangzhou, China when buying a house. In general, south facing houses are the most preferred as these houses will not be hit directly by the afternoon sun. House number is another important factor affecting households' housing preferences. For instance, house address numbers ending with eight such as 8, 18 and 28 would symbolize wealth and fortune whereas house address numbers ending with four such as 4, 14 and 24 or other numbers such as 13 are usually regarded as bad luck. In addition to house number, the sight of a cemetery is often viewed as bad fortune (Tse \& Love, 2000). They further showed that housing units with the view of a cemetery are usually lower in prices.

In summary, most home buyers want their homes to be located conveniently in relation to place of employment, schools, shops, recreational facilities and transportation. They may also place priority on the characteristics of the surrounding area, such as the quality of a dwelling, the

quality and cost of public facilities, social environment, absence of noise and pollution, and any prestige attached to the area. Based on previous empirical studies, there has been an interesting debate about the relative importance of these factors in housing preferences. Therefore, this paper intends to contribute to literature by developing an understanding on which housing attributes, as defined by locational, neighborhood, structural and socio-cultural attributes contribute to home owning preferences among first-time homebuyers in the Malaysian context.

\section{Social Demographic Characteristics of Respondents}

Home owning is a complex issue due to many factors including social-demographic descriptors. Most empirical studies have shown that home owning is strongly related to education, stages in life cycle, presence of children, and employment types. Therefore, a host of control variables was included in this model.

It is documented that family life cycle is strongly related to household size and marital status. An increase in the number of children in the household can result in a high homeownership rate (Goodman, 1990; Haurin \& Kamara, 1992; Coulson, 1999). Most agree that big households may purchase more housing than smaller ones. It is interesting to notice that the greater the number of 
children in the family, the less likely is homeownership (Bourassa, 1996). Even though it is expected that consumption of housing increases with household size, housing consumption can be crowed out by food consumption for very large household size (Laakso \& Loikkanen, 1995). Additionally, owner-occupied housing is often of better quality and more expensive than rented housing, as a result the preference to become a home owner is more prevalent among married couples than singles. Married households have significant and positive impacts on the homeownership rate. The male household heads are also expected to influence the likelihood of home owning (Coulson, 1999). It is due to the fact that male household heads tend to have high ownership rate as compared to female household head based on the assumption that male household heads have higher disposable incomes. However, the result of Goodman (1990) showed that the relationship is negatively significant, indicating that males exert less influence on homeownership. Furthermore, home ownership rate increases with the education of household heads (Laakso \& Loikkanen, 1995; Gwin \& Ong, 2004).

Not many housing studies have specifically investigated the types of organization in which household heads are employed on the likelihood of homeownership. However, Tan (2008) showed that employees from publicly-owned organizations consider ownership of a home as an investment tool for wealth accumulation. Tan (2008) further argued that employees from publicly-owned organizations are motivated to improve the quality of the neighborhood by holding a leading position in the local community organization as their working hours are fixed and predictable. High involvement in local politics may increase the propensity to own.

Given the preceding discussion, the research question is to assess whether structural, locational, neighborhood, and social cultural attributes of housing, and respondents' demographic characteristics exhibit statistically significant relationships for homeownership of first-time homebuyers in Greater KL.

\section{METHODOLOGY}

\section{Respondents}


In order to determine first-time buyers' home-owning preferences, a self-administered survey was conducted to collect the required data. The respondents, who are eligible to participate in the survey, are those who do not yet own a house, the main target of My First Home and the 1Malaysia People's Housing Schemes. However, a complete list of these respondents is not available to the researcher; therefore, samples were selected from four districts within Greater Kuala Lumpur, namely Cheras and Kuala Lumpur City in Kuala Lumpur and Subang Jaya and Petaling Jaya in Selangor state. Kuala Lumpur and Selangor states were selected because these two states contributed more than $45 \%$ of the total number of houses constructed in the country (Ministry of Finance's Valuation and Property Service Department, 2009). To ensure the eligibility of respondents, they were interviewed by using stratified sampling. The sampling criteria were: (1) the respondent is young working Malaysian in Greater KL, (2) the respondent has not ever purchased a house, and (3) the respondent earns less than RM 6,000 a month. The data were collected by face-to-face interviews. Following Reed and Mills (2007), preliminary questions, such as "Have you owned a house before?" were asked to determine eligible buyers under the schemes. Of 300 copies of survey forms received, 265 forms were used in this study.

\section{Variables used in this study}

The survey instrument of home owning was adapted from likert-scale measures contained in Tan (2008). The construct of home owning was an index or highly correlated item rather than a single-item question; therefore, the construction of the composite indices of home owning priorities was obtained from factor analysis. Based on factor analysis results, the unidimensional measure of home owning comprised of 5 questions (Cronbach's alpha 0.954): "home owning increases households' self-esteem", "home owning gives a feeling of achievement", "home owning creates wealth", "home owning improve the home environment in which a child lives" and "home owning increases households' self-satisfaction" with factor loadings of 0.725, 0.812, $0.741,0.725$ and 0.806 respectively. In this study, the composite index value of home owning construct is the average score of 5 survey items. It can be represented by:

$$
A H_{i}=\frac{1}{5} \sum_{j=1}^{5} H_{i j}
$$


where the index value of home owning $(\mathrm{AH})$ is the average score of homeownership $(\mathrm{H})$ construct, ${ }_{i}$ is $i$-th respondents, and ${ }_{j}$ is $j$-th questions.

The measure of housing attributes, as defined by locational, neighborhood, structural and sociocultural housing attributes was measured in a dichotomous code. Five locational housing attributes were considered in this study: distance to the workplace (Workplace), to shops (Retail), to schools (School), to recreational facilities (Recreational) and to public transportation centers (Transport). Neighborhood attributes included in the study were the level of neighborhood crime rate (Crime), neighborhood pollution (Pollution), neighborhood cleanliness (Cleanliness) and guarded neighborhood (Guarded). The number of bedrooms (Bedroom), bathroom (Bathroom), size of living area (Living), size of kitchen area (Kitchen), built-up area (Build-up) and green housing (Eco) were included to indicate structural attributes of the housing. Last, two socio-cultural housing attributes included in this study, namely house number (Number), and house orientation (Orientation). The survey also contains information relating to respondents' socio-demographic characteristics. As indicated earlier, home owning preferences may tend to vary by the socio-economic status of households. These include gender, marital status, presence of children, profession and education. Table 1 shows a summary of exploratory variables used in this study.

Table 1: Definition of Exploratory Variables in the Study

\begin{tabular}{|l|l|}
\hline \multicolumn{1}{|c|}{ Variables } & \multicolumn{1}{c|}{ Definition } \\
\hline Locational Attributes of Housing & $\begin{array}{l}1 \text { if the travelling distance to retailing outlets is a main consideration when } \\
\text { buying a house, 0 otherwise }\end{array}$ \\
\hline Retail & $\begin{array}{l}1 \text { if the travelling distance to the school is a main consideration when buying a } \\
\text { house, 0 otherwise }\end{array}$ \\
\hline Transport & $\begin{array}{l}1 \text { if the travelling distance to the public transportation station is a main } \\
\text { consideration when buying a house, 0 otherwise }\end{array}$ \\
\hline Workplace & $\begin{array}{l}1 \text { if the travelling distance to the workplace is a main consideration when } \\
\text { buying a house, 0 otherwise }\end{array}$ \\
\hline Recreation & $\begin{array}{l}1 \text { if the travelling distance to recreational parks is a main consideration when } \\
\text { buying a house, 0 otherwise }\end{array}$ \\
\hline Neighborhood Attributes of Housing \\
\hline Pollution & $\begin{array}{l}1 \text { if the level of pollution in the neighborhood is a main consideration when } \\
\text { buying a house, 0 otherwise }\end{array}$ \\
\hline
\end{tabular}




\begin{tabular}{|l|l|}
\hline Crime & $\begin{array}{l}1 \text { if the level of crime problem in the neighborhood is a main consideration } \\
\text { when buying a house, } 0 \text { otherwise }\end{array}$ \\
\hline Cleanliness & $\begin{array}{l}1 \text { if the cleanliness in the neighborhood is a main consideration when buying a } \\
\text { house, } 0 \text { otherwise }\end{array}$ \\
\hline Guarded & $\begin{array}{l}1 \text { if the guarded neighborhood is a main consideration when buying a house, } 0 \\
\text { otherwise }\end{array}$ \\
\hline Structural Attributes of Housing \\
\hline Bathroom & $\begin{array}{l}1 \text { if the number of bathroom is a main consideration when buying a house, } 0 \\
\text { otherwise }\end{array}$ \\
\hline Bedroom & $\begin{array}{l}1 \text { if the number of bedroom is a main consideration when buying a house, } 0 \\
\text { otherwise }\end{array}$ \\
\hline Living & $\begin{array}{l}1 \text { if the size of living area is a main consideration when buying a house, } 0 \\
\text { otherwise }\end{array}$ \\
\hline Kitchen & $\begin{array}{l}1 \text { if the size of kitchen area is a main consideration when buying a house, } 0 \\
\text { otherwise }\end{array}$ \\
\hline Eco & $\begin{array}{l}1 \text { if the eco-friendly home is a main consideration when buying a house, } 0 \\
\text { otherwise }\end{array}$ \\
\hline Built-up & $\begin{array}{l}1 \text { the built-up area of the house is a main consideration when buying a house, } 0 \\
\text { otherwise }\end{array}$ \\
\hline Social Cultural Attributes of Housing \\
\hline Orientation & $\begin{array}{l}1 \text { if the house direction is a main consideration when buying a house, } 0 \\
\text { otherwise }\end{array}$ \\
\hline Number & 1 if house number is a main consideration when buying a house, 0 otherwise \\
\hline Demographic Characteristics of Respondents \\
\hline Male & 1 if the respondent is male, 0 otherwise \\
\hline Married & 1 if the respondent is married, 0 otherwise \\
\hline Children & 1 if the respondent has children, 0 otherwise \\
\hline Pubic & 1 if the respondent is working in the public sector, 0 otherwise \\
\hline College & 1 if the respondent is a college graduate \\
\hline
\end{tabular}

A functional relationship in this study can be represented by:

$$
A H_{i}=\beta_{0}+\beta_{l} L_{i}+\beta_{n} N_{i}+\beta_{s} S_{i}+\beta_{s c} S C_{i}+\beta_{d} D_{i}+\varepsilon_{i}
$$

where $\beta_{l}$ is the coefficient vector for the locational attributes $(L)$ which measure the locational effect on home owning $(A H)$, while $\beta_{n}, \beta_{s}$ and $\beta_{s c}$ are neighborhood $(N)$, structural $(S)$ and social cultural $(S C)$ coefficient vectors, respectively, reflecting the neighborhood, structural and social cultural effects on home owning. $\beta{ }_{d}$ refers to the coefficient vectors of socio-demographic descriptors of respondents $(D) . \varepsilon$ is the stochastic disturbance vector. 


\section{RESULTS AND DISCUSSION}

There were two equations presented in the regression analysis. The first one is solely based on the effect of housing attributes on home owning without taking respondents' social demographic descriptors into consideration whereas the second equation includes social demographic characteristics as control variables. As shown in table 2, the first and second equation explained about 59 and 67 percent of variation in home owning priorities, respectively.

The results from both equations revealed that distance to retailing outlets was significantly and negatively related to homeownership at the 0.01 level holding all other things constant. After controlling control variables, first-time homebuyers are $27.6 \%$ less likely to own the house which is near retailing outlets. Negative impacts of retailing outlets on home owning may be generally attributed to noise and visual intrusion. As mentioned by Tse \& Love (2000), proximity to retailing outlets does not contribute to any positive impact on the house price. Additionally, the distance to the workplace and schools both were significantly and positively associated with home owning consideration after controlling socio-demographic characteristics. In this survey, $28.8 \%$ and $25.4 \%$ higher possibilities of home owning were observed for the houses that are not far away from the workplace and schools, respectively. This is consistent with the findings of Tan (2011a) as a long distance to workplace and schools means incurring more travelling time and cost which may affect home owning preferences. Similarly, the distance to recreational park was one of home-owning considerations when buying a house. However, the distance to public transportation centers was insignificantly related to home owning. It appeared that respondents in the survey have excluded these variables in determining the preference to become a home owner.

It seems that snatch thefts and rampant break-ins in Greater KL's urban area make first-time homebuyers a little more concerned about their personal security. The estimation results showed that neighborhood crime (in both equations) and guarded neighborhood (only the second equation) were significant determinants to influence the likelihood of home owning among firsttime homebuyers. Generally, these results were comparable to finding obtained in Tan (2011a) and indicated similar buyer behaviors in the housing market with reference to the security 
problem in the neighborhood. Additionally, the cleanliness in the neighborhood was one of the highly significant factors for first-time homebuyers to own their home. As for the effects of neighborhood pollution, the signs were expected but only statistically significant in the first equation.

Of six structural housing attributes, only the number of bedroom and the house with sustainable living features were significantly related to home owning. Similar to the findings of Opoku \& Abdul-Muhmin (2010), private living space such as the number of bedroom may appear to be an important structural attributes to be considered by first-time homebuyers in making home owning decisions. It could also be seen that the likelihood of home owning was $25 \%$ higher if the house has sustainable living features as eco-friendly homes reduce greenhouse gas emissions by using renewable or durable local resources for construction and adopting passive design principles into the floor plan to take advantage of natural breeze, warming sun and rainwater. However, the results showed that there were insignificant relationships in the preference to become a homeowner based on number of bathroom, size of living room, built up area and kitchen area.

In theory, homebuyers preferred houses that have good Feng Shui. It seems that the house with a good direction and house number could not raise the likelihood of home owning after taking controlled variables into consideration. It appeared that social cultural attributes of housing exerted less influence on home owning consideration among first-time homebuyers in Greater KL.

Among respondents' socio-demographic characteristics, males showed significant effect on homeownership, all other thing being equal. In line with previous works, the increase in households by men would tend to have increased the overall homeownership rates (Goodman, 1990; Coulson, 1999). In line with previous research, education appeared to be significant to home owning. Many studies confirmed the belief that homeownership increases as the educational level of households increases. For example, Gabriel (2001) reported that homeownership rates of college graduate were five percentage points higher than those of households who had not finished college in 1980, and four percentage points higher in 1990. As 
for the type of organization in which the household is employed, the estimation for the survey showed that, holding all other factors constant, employees from public sectors are $29.4 \%$ more likely to become homeowners. Government agencies generally hold a major responsibility in fulfilling the housing need of employees in the public sector, therefore the likelihood of home owning among employees from the government department is higher. In theory, home owners generally have bigger household size in terms of the number of children in the family. However, the result did not support the hypothesis that the presence of children was significantly related to the decision to own. As expected, the preference to become a homeowner is more prevalent among married respondents than among singles, but the relationship was not statistically significant.

Table 2: Effects of Housing Attributes on Home Owning Decisions

\begin{tabular}{|c|c|c|c|c|c|c|c|c|}
\hline \multicolumn{5}{|c|}{ Model 1} & \multicolumn{4}{|c|}{ Model 2} \\
\hline & B & $\begin{array}{c}\text { Std. } \\
\text { Error }\end{array}$ & Impact & VIF & $\mathrm{B}$ & $\begin{array}{c}\text { Std. } \\
\text { Error }\end{array}$ & Impact & VIF \\
\hline $\mathrm{C}$ & 3.108 & .202 & & & 2.545 & .198 & & \\
\hline Retail & $-.323 *$ & .067 & -.276 & 1.191 & $-.265 *$ & .061 & -.233 & 1.213 \\
\hline School & $.308 *$ & .071 & .361 & 1.339 & $.226 *$ & .067 & .254 & 1.450 \\
\hline Transport & .074 & .097 & .077 & 1.158 & .089 & .090 & .093 & 1.213 \\
\hline Workplace & $.280 *$ & .119 & .323 & 1.581 & $.253^{*}$ & .108 & .288 & 1.600 \\
\hline Recreation & $.230 *$ & .106 & .259 & 3.052 & $.226 *$ & .096 & .254 & 3.094 \\
\hline Pollution & $.429 *$ & .146 & .536 & 1.131 & .218 & .136 & .244 & 1.209 \\
\hline Crime & $.379 *$ & .095 & .461 & 1.334 & $.271 *$ & .089 & .311 & 1.441 \\
\hline Cleanliness & $.231 *$ & .104 & .260 & 2.640 & $.188^{*}$ & .095 & .207 & 2.734 \\
\hline Guarded & .160 & .110 & .174 & 1.123 & $.208 *$ & .100 & .231 & 1.145 \\
\hline Bathroom & -.093 & .131 & -.089 & 1.663 & -.076 & .118 & -.073 & 1.673 \\
\hline Bedroom & $.316^{*}$ & .099 & .372 & 1.560 & $.212 *$ & .090 & .236 & 1.606 \\
\hline Living & .209 & .109 & .232 & 1.701 & .157 & .099 & .170 & 1.727 \\
\hline Kitchen & -.082 & .076 & -.079 & 1.327 & .001 & .070 & .001 & 1.377 \\
\hline Eco & $.299 *$ & .100 & .349 & 2.630 & $.223 *$ & .091 & .250 & 2.729 \\
\hline Built-up & .107 & .146 & .113 & 1.637 & .114 & .132 & .121 & 1.670 \\
\hline Number & $.169 *$ & .069 & .184 & 1.284 & .118 & .063 & .125 & 1.328 \\
\hline Orientation & .023 & .072 & .023 & 1.388 & .013 & .065 & .013 & 1.400 \\
\hline Males & & & & & $.231 *$ & .057 & .260 & 1.241 \\
\hline Married & & & & & .063 & .085 & .065 & 2.729 \\
\hline Children & & & & & .025 & .089 & .025 & 2.733 \\
\hline
\end{tabular}




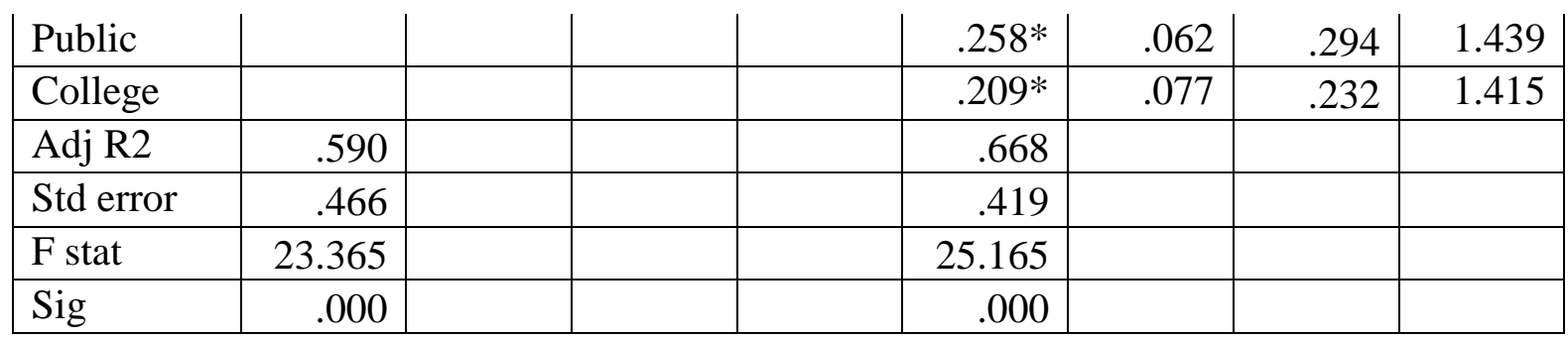

* Significance at 0.05

\section{CONCLUSIONS AND RECOMMENDATION}

This study is relevant to developers as it provides the necessary information to improve the housing delivery system by addressing housing needs of first-time homebuyers. In order to make a success of My First Home and PR1MA housing schemes, developers should be sensitive to first-time homebuyers' interests by determining factors relating to home owning priorities.

With prices of house in urban areas at an all time high, the environment has become difficult for first-time homebuyers to own a property. It is certainly time to introduce a more progressive and embracing social housing model to all needy Malaysians irrespective of race and religion. In order to ensure the success of the schemes, the schemes must be properly designed and planned for sustainability. Houses should be built and equipped with all the elements of healthy living, learning, and working as homebuyers find it more cost-effective to move into well-connected neighborhood.

From the analysis, respondents in the survey pay attention not only to the quality of dwelling unit but also the need to thrive in a good and safe environment in the neighborhood. Households find it increasingly challenging to deal with security issues in Greater KL owing to the country's escalating crime rate and break-ins. These factors have given rise to the new housing project, being marketed under the concept of gated community and guarded neighborhood. Homebuyers are enticed with the promise of privacy and restricted access; therefore, housing developers should help house buyers develop a safe and secure neighborhood.

The results also showed that the variables associated with locational attributes of housing such as the distance to retailing outlet, schools, recreational parks and workplace are found to be 
significant to home owning. There is a need for the government to build houses in the target area that come together with infrastructure and employment opportunities. Following the experience of Housing Development Board (HDB) in Singapore, housing infrastructure and areas should be developed with the concept of communal activities. The rationale behind this would be to build a close and sustainable knit community where house buyers can find the place within the area to work, shop and school. As indicated earlier, many public housing developments have turned into slums that do not provide decent environment for families to thrive in. It is sensible that more decent housing facilities that provide an improved quality of life are provided to inhabitants so that they will not end up without proper housing and add to the many social woes already plaguing the Greater KL.

The analysis of home owning preference also indicated that first-time homebuyers have begun to tread the path of eco-friendly housing and recognize the value of going green. The issues of sustainability have become ever more paramount in today's housing market as homebuyers generally understand practices that can lead to more environmentally friendly and ecologically responsible decisions and lifestyles which can help protect the environment and sustain its natural resources for current and future generations. Therefore, housing developers should recognize the growing market demand for environmentally sustainable housing development projects by constructing houses for sustainable living, which is in tandem with the government's efforts to go green. The Malaysian government has highlighted far reaching carbon emission reduction of up to 40 percent of the 2005 levels which were at 187 million tones. While an overall master planning will ensure the housing projects under the scheme have all the right attributes and required property mix, developers should be encouraged to be creative on the design and concepts of these projects by incorporating green features.

Government bodies and developers should look into ways to help ease the younger generation's burden due to the rising construction cost and land prices in Greater KL. In order to provide greater opportunity for first-time homebuyers to acquire homes costing from RM 100, 000 to RM 300, 000, there is a need for the federal government and the state government to work in unison with housing developers to build homes for them. Instead of leaving the responsibility to build the house under the schemes to governments, it should be a joint initiative between 
governments and developers. Since land matters in Malaysia falls under the jurisdiction of state governments; it is advisable that these governments provide and allocate enough parcels of good government land for the projects, while the developers provide their expertise. Furthermore, both federal and state governments should be very transparent about logistics, location, pricing and implementation to ensure that there is action behind the words.

In order to increase home ownership among young working Malaysians, it is important that this form of affordable housing under the scheme does not one day become the disenchantment of Greater KL. There are lessons to be learnt from public low-cost housing schemes in the past as most low-cost housing areas have turned into slums. There should be well thought out and clearly defined master planning as well-planned infrastructure will add value to the living environment and quality of life. In order to prevent subsidized houses housing ending up in the hands of speculators who want to make profits from the property, the government should enact strict laws and regulations to ensure that this type of housing only benefits first-time homebuyers who need genuine help for basic housing need. Households who are not eligible for My First Home and PR1MA housing schemes should not be allowed to access this type of housing. In addition, homebuyers under the schemes are not allowed to sell their homes on the market for profit within the first 5 years. An exit system is required for households who return their subsidized housing to the government if they want to dispose off their first homes in the hope that other first-time homebuyers in need can benefit from this scheme. These homes can only be repurchased by the government at a relatively low price.

\section{REFERENCES}

Aarland, K., \& Nordvik, V. (2007). Low income households and the dynamics of housing demand, Proceeding of European Network for Housing Research Conference, Rotterdam.

Al-Hagla, K. (2008). Towards a sustainable neighbourhood: the role of open spaces, International Journal of Architectural Research, 2 (1), 162 - 177.

Annuar, A. (2011) Bill to set up PR1MA to be tabled soon, The Sun Daily, July 5. $\langle$ http://www.thesundaily.my/news/67914> 
Bhatti, M., \& Church, A. (2004). Home, the culture of nature and meanings of garden in late modernity, Housing Studies, 19, 37 - 51.

Bourassa, S. C. (1996). Measuring the affordability of homeownership, Urban Studies, 33 (10), $1867-1877$.

Cheng, T. L. (2011) Will buyers be proud of My First Home? The Star, March 19. SBW 26.

Choguill, C. L. (2008). The search for policies to support sustainable housing, Habitat International, $31,143-149$.

Clark, W., Deurloo, M., \& Dieleman, F. (2006). Residential mobility and neighborhood outcomes, Housing Studies, 21, 323 - 342.

Clark, W., \& Onaka, J. (1983). Life cycle and housing adjustment as explanations of residential mobility, Urban Studies, 20, 47 - 57.

Coulson, N. E. (1999). Why are Hispanic- and Asian-American homeownership rates so low? immigration and other factors, Journal of Urban Economics, 45, 209 - 227.

Crane, R. (1996). The influence of uncertain job location on urban form and journey to work, Urban Studies, 39, 342 -356.

Cupchik, G., Ritterfeld, U., \& Levin, J. (2003). Incidental learning of features from interior living spaces, Journal of Environmental Psychology, 23, 189 - 197.

Fierro, K., Fullerton, T. \& Donuan-Callejo, K. (2009). Housing attributes preference in a northern Mexico metropolitan economy, Atlantic Economic Journal, 37, 159 - 172.

Foley, D. (1980). The sociology of housing, Annual Review Social, 6, 457 - 478. 
Friedman, A. (2000). Preferences of first-time buyers of affordable housing: evidence from grow homes in Montreal, Canada. Canadian Journal of Urban Research, 9 (1), 1- 22.

Gabriel, S. A. (2001). The decision to own, Mortgage Banking, 62 (1), 419 - 444.

Goodman, A. C. (1990). Demographic of individual housing demand, Regional Science and Urban Economics, 20, 83 - 102.

Green, R. K. \& White, M. J. (1997). Measuring the benefits of homeowning: effects on children, Journal of Urban Economics, 414, 441 - 461.

Gwin, C. R., \& Ong, S. E. (2004). Do we really understand home ownership rates? An international study. Baylor University, Working Paper Series.

Haurin D. R., \& Kamara, D. (1992) The homeownership decision of female-headed households, Journal of Housing Economics, 2 (4), 293 - 309.

Haurin, D. R., Parcel, T. L., \& Haurin, R. J. (2002). Does homeownership affect child outcomes? Real Estate Economics, 30 (4), 635 - 666.

Hurtubia, R., Gallay, O., \& Bierlaire, M. (2010). Attributes of households, locations and realestate markets for land use modeling, Sustain City Working Paper, 2.7, EPFL, Lausanne.

Iman, A., Hamidi, N., \& Liew, S. (2009) The effects of environmental disamenities on house prices, Malaysia Journal of Real Estate, 4, 31 - 44.

Jabareen, Y. (2005). Housing preferences in a developing city, Environment and Behavior, 37, $134-146$.

Karim, H. (2008). The satisfaction of residents on community facilities in Shah Alam, Malaysia, Asian Social Science, 4, 131 - 137. 
Kauko, T. (2007). An analysis of housing location attributes in the inner city of Budapest, Hungary, using expert judgment, International Journal of Strategic Property Management, 11, $209-225$.

Laakso, S., \& Loikkanen, H. A. (1995). Finnish homes - through passages or traps? Real Estate Economics, 23 (4), $475-495$.

Levine, J. (1998). Rethinking accessibility and jobs-housing balance, Journal of the American Planning Association, 64, 133- 149.

Lindberg, E., Garling, T., \& Montgomery, H. (1989). Belief-value structures as determinants of consumer behavior: a study of housing preferences and choices, Journal of Consumer Policy, 12, $119-137$.

Luttik, J. (2000). The value of trees, water and open spaces as reflected by house price in the Netherlands, Landscape and Urban Planning, 48, 161 - 167.

Lo, A., \& Jim, C. (2010). Willingness of residents to pay and motives for conservation of urban green spaces in the compact city of Hong Kong, Urban Forestry and Urban Greening, 9 (2), $113-120$.

Ministry of Finance's Valuation and Property Service Department. (2009). Property Market Status Report (Kuala Lumpur, Government Printer)

Ministry of Finance's Valuation and Property Service Department (2010). Property Market Status Report Q3 (Kuala Lumpur, Government Printer)

Ministry of Finance's Valuation and Property Service Department (2011). Property Market Status Report Q1 (Kuala Lumpur, Government Printer) 
Opoku, R. \& Abdul-Muhmin, A. (2010). Housing preferences and attributes importance among low-income consumers in Saudi Arabia, Habitat International, 34, 219 - 227.

Reed, R., and Mills, A. (2007) Identifying the drivers behind housing preferences of first-time owners, Property Management, 25 (3), 225 - 241.

Rohe, W. M., Van Zandt, S., \& McCarthy, G. (2001). The social benefits and cost of homeownership: a critical assessment of research, low-income homeownership, working paper series, Joint Center for Housing Studies, Harvard University.

Saunders, P. (1990). A Nation of Home Owners. (London, Unwin Hyman).

Segerson, K. (2001). Real estate and the environment: an introduction, The Journal of Real Estate, Finance and Economics, 22, 135 - 139.

Sultan Sidi, N. (2010). Quality affordable housing: a theoretical framework for planning and design of quality housing, Journal of Tecno-Social, 2, 1 - 10.

Tajima, K. I. (2003). New estimates of the demand for urban green space: implications for valuing the environmental benefits of Boston's big dig project, Journal of Urban Affair, 25, 641 -655 .

Tan, T.H. (2008). Determinants of homeownership in Malaysia, Habitat International, 32, 318 335.

Tan, T. H. (2009). Homeowning motivation in Malaysia, Journal of Accounting-Business and Management, 16(1), 93 - 112.

Tan, T. H. (2011a). Neighborhood preferences of house buyers: the case of Klang Valley, Malaysia, International Journal of Housing Markets and Analysis, 4(1), 58 - 69. 
Tan, T. H. (2011b). Measuring the willingness to pay for houses in a sustainable neighborhood, The International Journal of Environmental, Cultural, Economic and Social Sustainability, 7, 1 12.

Tan, T. H. (2011c). Housing satisfaction in medium- and high-cost housing: the case of Greater Kuala Lumpur, Malaysia, Habitat International, DOI: 10.1016/j.habitatint.2011.06.003.

Tse, R. C. C. \& Love, P. E. D. (2000). Measuring residential property values in Hong Kong, Property Management, 18, 366- 374.

Tu, Y., \& Goldfinch, J. (1996). A two-stage housing choice forecasting model, Urban Studies, $33,517-537$.

Wang, D., \& Li, S.M. (2006). Socio-economic differentials and stated housing preferences in Guangzhou, China, Habitat International, 30, 305 - 326.

$\mathrm{Xu}$, P. (1998). Feng-shui models structured traditional Beijing courtyard houses, Journal of Architectural and Planning Research, 15, 271 - 282.

Yam, L. H. \& Ismail, M. (2008). Corporate social responsibility in Malaysia housing development house-buyers' perspectives, Proceeding for the $14^{\text {th }}$ Pacific Rim Real Estate Society Conference, Kuala Lumpur.

Yusuf, A., \& Resosudarmo, B. (2009). Does clean air matter in developing countries' megacities? A hedonic price analysis of the Jakarta housing market, Indonesia, Ecological Economics, 66, 1398 - 1407.

Zabel, J., \& Kiel, K. (2000). Estimating the demand for air quality in four U.S. cities, Land Economics, 76, $174-194$. 